Научная статья

УДК 371.12

DOI: $10.18101 / 2307-3330-2021-3-32-36$

\title{
ПРОБЛЕМЫ ПРОФЕССИОНАЛЬНОГО СТАНОВЛЕНИЯ И РАЗВИТИЯ СОВРЕМЕННЫХ МОЛОДЫХ УЧИТЕЛЕЙ
}

\author{
(C) Маланов Иннокентий Александрович \\ профессор, кандидат педагогических наук, \\ Бурятский государственный университет имени Доржи Банзарова \\ Россия, 670000, г. Улан-Удэ, ул. Смолина, 24a \\ imalanov52@mail.ru
}

\begin{abstract}
Аннотация. В статье рассмотрен ряд проблем профессионального становления и развития молодых педагогов общеобразовательных организаций в современных социальноэкономических условиях. Одной из нерешенных проблем профессиональной адаптации молодых учителей является их слабая практическая готовность к профессиональной деятельности, что влечет за собой отток молодых кадров из школы. Автор дает сравнительный анализ практической подготовки будущих педагогов в отечественных и зарубежных вузах, показывая, в каких аспектах необходимо усилить эту подготовку.

Еще одной из причин, отражающихся негативно на профессиональной адаптации начинающих педагогов, является бюрократизация их труда, и автор считает, что это не способствует творческому росту молодежи в педагогических коллективах школ. Кроме того, автор считает необходимым пересмотреть феномен наставничества с учетом современных реалий состояния образовательной практики. Автор отмечает необходимость системного решения обозначенных в статье проблем профессиональной адаптации молодых педагогических кадров в современных общеобразовательных школах.

Ключевые слова: профессиональное становление, профессиональное развитие, молодые педагоги, практическая подготовка педагогов, профессионально-педагогическая подготовка, теоретическая подготовка педагогов, профессиональная деятельность педагогов, наставничество, институализация наставничества.
\end{abstract}

\section{Для цитирования}

Маланов И. А. Проблемы профессионального становления и развития современных молодых учителей // Вестник Бурятского государственного университета. Образование. Личность. Общество. 2021. № 3. С. 32-36.

Одна из актуальных проблем современного образования - стремительное старение педагогических кадров, причем на всех уровнях, как в высшем образовании, так и в общеобразовательных школах.

Правительством РФ предпринимаются меры по поддержанию материального положения молодых педагогов, повышению их профессиональной квалификации, организации наставничества. Но, несмотря на это, количество молодых специалистов, занимающихся педагогической деятельностью, из года в год уменьшается.

Данное плачевное положение с молодыми кадрами в образовании во многом обусловлено сложным социально-экономическим положением, сложившимся в стране. 
И. А. Маланов. Проблемы профессионального становления и развития современных молодых учителей

Кроме того, молодежь не задерживается в школе из-за трудностей в работе, с которыми они сталкиваются в начале своего профессионального становления.

Трудности, возникающие у молодых учителей в процессе обучения детей из-за недостаточной их практической подготовки, значительно снижают интерес к своей профессиональной деятельности и негативно отражаются на качестве образования обучающихся. Это, в свою очередь, вызывает у молодых учителей неверие в свои силы и побуждают молодых специалистов к смене сферы своей профессиональной деятельности.

Таким образом, высокий уровень практической профессионально-педагогической подготовки является важным фактором стабильной профессиональной деятельности молодых педагогов, поддерживая у них интерес к своей профессии. Обращаясь к зарубежному опыту, можно констатировать, что в программах профессиональной подготовки учителей значительное место отводится педагогической практике студентов в школе, каждый будущий учитель должен отработать на стажировке в школе не менее одного года при консультативной помощи учителей. Педагогическая практика должна быть встроена в теоретический учебный курс, а преподаватели строго следят за тем, как у них формируются умения руководить классом, держать дисциплину, оценивать учебные достижения обучающихся.

По данным зарубежных исследователей, опрашивавших российских учителей моложе 25 лет и старше 55 лет, профессиональная подготовка в наших вузах за 30 лет в аспекте формирования практической готовности у будущих учителей не изменилась. Все также доминирует теоретическое образование. Между тем в мировой практике в профессиональной подготовке учителей наметилась устойчивая тенденция к увеличению бюджета времени в их образовательной программе на изучение методики преподавания и формирования практических навыков [3].

Обращаясь к зарубежному опыту подготовки учительских кадров, необходимо отметить положительный подход в педагогическом профессиональном образовании, например, в некоторых странах в качестве средства введения в профессию используется год учительской практики в школе при поддержке связи с вузом. В ходе преподавательской практики отрабатываются умения и навыки использования инновационных технологий и методик обучения, а также проверяется экспериментальное исследование по теме выпускной квалификационной работы.

В зарубежных странах в процессе профессионального образования учителей уделяют особенное внимание развитию исследовательских, аналитических компетенций в плане их практического использования в преподавательской практике. В процессе педагогического образования в ряде зарубежных стран будущих учителей учат как изучать условия, факторы и механизмы, влияющие на качество обучения детей, как оказывать помощь отстающим, справляться с конфликтными ситуациями в классе и др. К сожалению, в профессиональной подготовке педагогов в нашей стране этому не уделяют должного внимания, в связи с небольшой долей бюджета времени, уделяемого практическому обучению.

По мнению российских исследователей, молодые педагоги имеют ограниченный доступ к полноценному профессиональному развитию, так многие из опрошенных среди причин ограничения называют нехватку времени из-за выполнения семейных 
обязанностей, неудобный график работы, не позволяющий заниматься повышением своей профессиональной квалификации. Вместе с тем, по отзывам самих молодых учителей, представители администраций образовательных организаций не препятствовали их стремлению к профессиональному развитию. Более $26 \%$ учителей, чей возраст не превышает 29 лет, считают, что у них недостаточный опыт и невысокий уровень квалификации, что является препятствием для их профессионального развития, т. е. молодые учителя весьма критично оценивают уровень своей профессиональной квалификации и высказывают повышенные запросы на профессиональное развитие [3].

Анализ тех направлений профессиональной деятельности, в которых они хотят совершенствоваться, косвенно свидетельствует об уровне их профессиональной подготовки, который они получили в вузе. Так молодые педагоги недостаточно уверенно владеют педагогическими технологиями, которые бы соответствовали ФГОС и профессиональному педагогическому стандарту (к ним относятся, например, методы индивидуального развития обучающихся или особенности обучения детей с ограниченными возможностями по состоянию здоровья), что позволяет говорить о недостатках в системе подготовки педагогических кадров.

Опрос молодых педагогов показывает, что они зачастую остаются один на один с детьми и трудностями, возникающими у них в ходе профессиональной деятельности. Хотя формально за ними закреплены наставники, однако они не всегда могут получить достоверные сведения о своей работе, т. к. это требует довольно большого количества времени и внимания со стороны наставников и представителей администрации образовательных организаций, которого у них зачастую нет. $28 \%$ молодых учителей отмечают дефицит профессиональной коммуникации. Между тем именно молодым, начинающим педагогам, нужна эта обратная связь, чтобы правильно оценить свои профессиональные умения и навыки и продумать с помощью своих старших товарищей как их совершенствовать. Молодежь достаточно критично относится к предлагаемым администрациями образовательных учреждений планам для повышения квалификации, т. к. считают, что они не основаны на объективном анализе и оценке профессиональной работы учителей. Молодые педагоги, по их мнению, нуждаются в тесном взаимодействии с более опытными учителями, но они зачастую остаются в стороне от группового взаимодействия по решению педагогических проблем из-за, как они считают, недостатка педагогического опыта, мастерства.

Молодые педагоги не достаточно высоко оценивают свои преподавательские умения и навыки, отдавая первенство более опытным и коллегам, что во многом соответствует реальному положению дел. Наибольшие трудности для молодых представляют умение организовать у учащихся учебную деятельность, т. е. поддержание дисциплины в классе.

Как показывает наблюдения за работой молодых учителей, учащиеся на их уроках имеют меньше возможностей для занятия активной самостоятельной работой во многом из-за ограниченного набора методов и обучающих технологий, применяемых начинающими педагогами на уроке [1].

Можно сделать предположения, что недостаток владения молодыми педагогами методов и приемов организации, обучения, которым их не оснастили вузовские педа- 
И. А. Маланов. Проблемы профессионального становления и развития современных молодых учителей

гоги приводит к тому, что молодые педагоги больше времени на уроке отводят установлению и поддержанию дисциплины, поэтому они не уделяют в полной мере использованию при обучении инфо-коммуникационные технологии, хотя именно в этом аспекте профессиональной подготовки они гораздо сильнее, чем учителя со стажем.

Как показывают результаты исследования профессиональной подготовки молодых учителей, наибольшие трудности они испытывают при применении методов оценивания, т. к. большинство используют традиционные методики, не рискуя применять инновационные инструменты оценивания учебной деятельности учащихся [1].

Еще одной причиной, которая негативно отражается на профессиональной деятельности молодых педагогов, является тенденция ко все большей бюрократизации труда педагогов в российских школах по сравнению с их коллегами из зарубежных школ. Несмотря на изданный Министерством просвещения РФ закон, направленный на уменьшение бюрократической нагрузки на учителей, проблема не только не решается, а наоборот в последнее время все более усугубляется. По данным исследования занятости педагогов доля трудозатрат российских педагогов на решение бюрократических задач во многом превышает время, потраченное их зарубежными коллегами из Финляндии, Канады, Японии, Китая и многих других стран [4]. Однозначно, что эти проблемы являются системной и требуют направленных усилий как со стороны региональных органов управления образования, так со стороны Министерства просвещения РФ. Освобождение учителя от бюрократической работы позволит ему заниматься живой, творческой педагогической работой.

Безусловно, профессиональному развитию молодых педагогов, их скорейшей адаптации к требованиям школьного образования может способствовать наставничество. Однако наставничество не дает такого эффекта, которого от внедрения этой системы ожидали. Это показывают результаты исследования данной проблемы [2]. По мнению исследователей, основными причинами низкой эффективности наставничества является, во-первых, низкая информированность молодых педагогов о своих недостатках в профессиональной деятельности и их понимании, что им необходимо профессиональное взаимодействие с более опытными учителями, во-вторых, более опытные педагоги не очень хотят тратить свое время на помощь молодежи. Вместе с тем можно понять опытных педагогов, которые не хотят заниматься этой трудоемкой работой дополнительно и бесплатно. Поэтому, по мнению исследователей, необходимо решать вопрос о работе наставников системно, т. е. продумать какой это вид нагрузки будет у наставников, как он будет оплачиваться, какое внимание этому вопросу должна уделять администрация образовательных организаций. Как справедливо считают исследователи, дальнейшее развитие наставничество как системы требует ее институализации [2].

В целом проблема омоложения педагогических кадров носит системный характер, сразу ее решить невозможно. Но вместе с тем ее решение необходимо при совместном заинтересованном взаимодействии представителей педагогической науки, практических работников, а также органов управления образованием. Нами затронуты лишь некоторые аспекты профессионального становления и развития молодых педагогов, а для полного изучения данной проблемы необходимы более глубокие и системные исследования и решения. 
Лuтература

1. Куликова А. А. Образ молодого учителя в современных российских и зарубежных исследованиях // Отечественная и зарубежная педагогика. 2018. Т. 1, № 1 (46). С. 81-93.

2. Марголис А. А., Аржаных Е. В., Хуснутдинова М. Р. Институционализация наставничества как ресурс профессионального развития российских педагогов // Вопросы образования. 2019. № 4. С. 133-159. Текст: непосредственный.

3. Пинская М. А., Пономарева А. А., Косарецкий С. Г. Профессиональное развитие и подготовка молодых учителей в России // Вопросы образования. 2016. № 2. С. 100-124. Текст: непосредственный.

4. Полутин С. В., Мананникова Ю. В. Процессы бюрократизации и дебюрократизации учительского труда и их влияние на качество профессиональной деятельности педагогов: результаты социологического проекта // Integration of education. 2020. Vol. 24, no. 1. Текст: непосредственный.

Статья поступила в редакцию 18.11.2021; одобрена после рецензирования 22.11.2021; принята к публикащчи 07.12.2021.

\title{
PROBLEMS OF PROFESSIONAL FORMATION AND DEVELOPMENT OF MODERN YOUNG TEACHERS
}

\author{
Innokentiy A. Malanov \\ Professor \\ Dorzhi Banzarov Buryat State University \\ 24a Smolina St, Ulan-Ude, 670000, Russia \\ E-mail: imalanov52@mail.ru
}

The article deals with a number of problems of professional adaptation and development of young teachers of educational institutions in modern socio-economic conditions. One of the unsolved problems of the professional adaptation of young teachers is their weak practical readiness for professional activity, which entails an outflow of young staff from school. The author gives a comparative analysis of the practical training of future teachers in domestic and foreign universities, showing in what aspects it is necessary to strengthen this training.

Another reason that negatively affects the professional adaptation of novice teachers is the bureaucratization of their work, and the author believes that this does not contribute to the creative growth of young people in the teaching staff of schools.

In addition, the author considers it necessary to revise the phenomenon of mentoring, taking into account the modern condition of educational practice. The author notes the need for a systematic solution of the problems of young pedagogical staff professional adaptation in modern secondary schools identified in the article.

Keywords: professional adaptation, professional development, young teachers, practical training of teachers, professional and pedagogical training, theoretical training of teachers, professional activities of teachers, mentoring, institutionalization of mentoring.

The article was submitted 18.11.2021; approved after reviewing 22.11.2021; accepted for publication 07.12.2021. 